\title{
INDOCTRINATION AND BRAINWASHING PROCESS IN THE CASE \\ OF TERRORISM: A PSYCHOLOGICAL ANALYSIS OF SUICIDE BOMBING IN SURABAYA, EAST JAVA
}

\author{
Mohammad Takdir \\ Institut Ilmu Keislaman Annuqayah Guluk-Guluk Sumenep \\ Guluk-Guluk Sumenep, Madura, Indonesia, \\ E-mail: mohammadtakdir86@gmail.com
}

\begin{tabular}{|c|c|c|}
\hline Received & Revised & Approved \\
$12 / 04 / 2020$ & $27 / 06 / 2020$ & $30 / 06 / 2020$ \\
\hline
\end{tabular}

DOI: https:// doi.org/10.32332/akademika.v25i1.1990

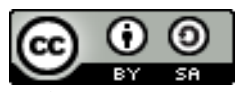

Indoctrination and Brainwashing Process in the Case of Terrorism:

A Psychological Analysis of Family Suicide Bombing in Surabaya, East Java

Licensed Under a Creative Commons Attribution-ShareAlike 4.0

International License

\begin{abstract}
This paper analyses the process of indoctrination and brainwashing in the case of terrorism. This study uses a psychological approach to uncover the suicide bombing case in Surabaya which has happened in Mei 2018. By using a case study, this research effort to understand deeply the psychological phenomenon that encourages terrorists to invite their families like suicide bombers. This research shows that the indoctrination process is done by giving video on jihad. This indoctrination process is an important stage in the cultivation of radical ideologies through preradicalization, self-identification, and jihadization. In this study, it was found that there are some stages of brainwashing for suicide bombers, namely the recruitment process, the indoctrination stage, and the isolation to do an attack of suicide bombing.
\end{abstract}

Key Word: Brainwashing, Indoctrination, Suicide Bombing, Terrorism 


\section{A. Introduction}

The acts of terrorism in several regions made people more worried and afraid of the threat of radical movements that did not recognize territorial boundaries or geographical locations. In Indonesia, acts of terrorism through suicide bombings have become a tool practiced by terrorists in justifying the religious doctrine. Today, suicide bombing is a very aggressive form of terrorism in the dynamics of people's lives. In the case of terrorism, terrorists use religious doctrine to justify suicide bombing actions as a way towards heaven. ${ }^{1}$

The suicide bombing is part of a radical movement that became a threat to the peace and security of the people. ${ }^{2}$ In Indonesia, suicide bombings are carried out in the name of defending religion. In many places, terrorism networks are indeed paralyzed by Detachment 88, but terrorist cadres are still hanging around building new networks that are more organized. For example, the suicide bomb explosion that occurred in Surabaya on May 2018, reflected a network that was so neat and wellorganized that the police were unable to detect suicide bomb planning that killed many victims at three churches in Surabaya.

In the case of a suicide bombing in Surabaya, it was carried out with an attack plan and strategy that was in line with the target. ${ }^{3}$ It shows a new trend in the jihadist movement with very mature planning an attack operation. Moreover, the new model in the development trend of terrorism in Surabaya involves kinship or family networks, including the involvement of his wife and children. The terrorism movement does need careful and organized planning. Habits and target movements (objects) must be observed. On the other hand, operational techniques of weaponry or bombs must be fully mastered by the perpetrators to make it easier to carry out their actions on the ground. ${ }^{4}$ It is almost certain that terrorist

${ }^{1}$ Robert A. Pape, Dying to Win: The Strategic Logic of Suicide Terrorism (New York: Random House Trade Paperbacks, 2006), 231.

2 Robert J. Brym dan Bader Araj, "Suicide Bombings as Strategy and Interaction: The Case of the Second Intifida," Social Forces 84, no. 4 (2006): 230.

${ }^{3}$ Kirsten E. Schulze, "The Surabaya Bombings and the Evolution of The Jihadi Threat in Indonesia," Combating Terrorism Center 11, no. 6 (2018): 12-15.

4 Lloyd Pettifor dan David Holding, Terrorism: The New World War (Bookmart Limited, 2003), 134. 
movements in Indonesia are always well planned so it is very difficult to be identified before a suicide bombing.

The acts of terrorism in Surabaya became clear evidence of the dangers of radical movements that continue to threaten the peace and peace of the people. Moreover, terrorism as a radical movement has a very strong network in producing militant cadres who are ready to become "brides of heaven". ${ }^{5}$ The terrorists' ingenuity in building networks makes the police must always be prepared to anticipate indications of suicide bombings in various regions in Indonesia.

Researchers took the example of a suicide bombing carried out by one family in Surabaya in three places at the same time. Three acts of terrorism in Surabaya carried out by one family involving women and children are a new phenomenon that could be the first in the world. Based on family photos circulating on various social media, they appear to be a normal family and even come from the middle class. ${ }^{6}$ This indicates that the development trend of terrorism has increased very significantly along with many new modes practiced by terrorists.

The Surabaya bombing case is evidence of how the family has a strategic position in each series of acts of terrorism? Previously, the suicide bombing was carried out by a single perpetrator, but now there has been a very significant paradigm shift in the pattern of attacks and family involvement. As it is known that Surabaya suicide bombings in three churches were carried out by one family, namely Dita Oeprianto (father), his wife, and four children. The first bomb attack occurred at the Church of Santa Maria Tanpa Bercela carried out by the oldest and second oldest child. The second bomb attack occurred at the Indonesian Christian Church with a mother with two children who blew themselves up, fifteen minutes after the first bomb attack. And the third bomb was carried out by

${ }^{5}$ V.G. Julie Rajan, Women Suicide Bombers: Narrative of Violence (New York: Routledge, 2011), 225.

${ }^{6}$ Noor Huda Ismail, "Ideologi Kematian Keluarga Teroris," CNN Indonesia (blog), Mei 2015, https://m.cnniindonesia.com/nasional/20180515. 
Dita by driving a car that was detonated in Pentakosta Church, forty-five minutes after the second bomb. ${ }^{7}$

Symptoms of the emergence of terrorism along with a series of actions carried out, including suicide bombings in Surabaya, have three important elements that influence acts of terrorism. First, the ideology of terrorism. This ideology occupies an important position because one cannot possibly carry out suicide bombings without being based on a strong ideology. Second, terrorist organizations that are developing rapidly in various parts of the world, thus affecting the intensity of acts of terrorism that occur in society. Third, it relates to the recruitment patterns of terrorist members who are increasingly massive and well-organized. The difference in recruitment patterns is one strategy to get a heaven bride who is indoctrinated by lucrative teaching. ${ }^{8}$

The fertility of the radical movement can indeed be seen from many factors as above, but this research only focuses on the psychological perspective that seeks to find out the motivations that can get a person involved in acts of terrorism. In Sarlito Wirawan's research, it was stated that initially a group of people merely went along (without knowing what happened) to carry out extreme jihad that was willing to sacrifice their souls in the name of the truth they believed. Apart from differences in motivation found in a person, there are similarities between the perpetrators. One of them wants to improve the situation that they consider unfair and not in line with Islamic teachings. ${ }^{9}$

The suicide bombing case in Surabaya showed a change in the strategy of the attack carried out by terrorist groups by making the family network a deadly weapon. Recruitment of women in terrorism cases is considered to have a strategic role to be active in the activities of terrorist organizations. ${ }^{10}$ Acts of terrorism involving this family network certainly

7 Rindha Widyaningsih, "Family Suicide Bombing: A Psychological Analysis of Contemporary Terrorism," Walisongo: Jurnal Penelitian Sosial Keagamaan 16, no. 2 (2018): 295-320.

8 A.H. Hendropriyono, Terorisme: Fundamentalisme Kristen, Islam, dan Yahudi (Jakarta: Kompas, 2009), 23.

9 Sarlito Wirawan Sarwono, Terorisme di Indonesia; dalam Tinjauan Psikologi (Jakarta: Pustaka Alvabet, 2012), 123.

10 Katharina Von Knop, "The Female Jihad: Al-Qaedah's Women," Studies in Conflict $\mathcal{E}$ Terrorism 30, no. 5 (2007): 397-414. 
cannot be separated from the process of brainwashing that is carried out massively against the brain and thoughts of terrorists in Surabaya.

From the background, this study seeks to uncover the process of indoctrination of terrorist wives and children in providing confidence that the ideology of death with a suicide bomb will deliver ultimate happiness by becoming a bride of heaven. Therefore, this research also trying to understand how the stages of brainwashing carried out by terrorists against their wives, children, and those family to them so that they do not have awareness in carrying out acts of terrorism through suicide bombings.

\section{B. Chronology, Profile, and Motives of Terrorism}

This section describes cases of terrorism in East Java that took place in three different Church locations at almost the same time in May 2018. This terrorism case in East Java became the largest case that took a lot of attention from various groups, ranging from the government, academics, religious leaders, and society in general. There are several reasons why the terrorism case in Surabaya has drawn a lot of attention and is highlighted as a human tragedy that has caused many victims. First, the terrorism case in Surabaya is carried out by one family with a suicide bombing at almost the same time. Second, terrorism cases involve women as the main driver to carry out terrorist acts and involve children as part of jihad.

\section{Chronology of the Bombings}

Then, what about the chronological facts of the terrorism case in Surabaya, East Java, which occurred in three churches at the same time? From several locations of the suicide bombing, it is important to describe its chronology, starting from the time, target, type of attack, weapons, death toll, and perpetrators who were part of the suicide bombing in Surabaya, East Java. Every terrorism event raises new facts that can be examined as an illustration in looking at the characteristics and strategies of attacks carried out by a group of terrorists in launching their actions with various approaches.

First, the first bomb explosion occurred at the Santa Maria Tanpa Maria Church. This suicide bomb explosion occurred when a motorcycle driven by 2 boys named Joseph (18 years) and Firman (16 years) entered the church compound and then crashed into one of the congregations 
before finally exploding among the crowd of congregations who were walking on the lawn Church. The suicide bomb explosion occurred at 6:30 am and killed 7 people ( 2 suspects and 5 other civilians). ${ }^{11}$

Secondly, a bomb blast occurred at the Indonesian Christian Church on the Street Diponegoro. The suicide bomb explosion at the Indonesian Christian Church occurred at around 07.30. The killer was a woman carrying two children and carrying a large bag as evidence of the incident. Based on CCTV monitoring, the suicide bomber then enters the church in the convention room but is not allowed inside because he does not get permission from security guards or security forces. Before they left the Church, the woman blew herself up in front of the Church while hugging the security guard who was holding a church service. The suicide bomber at GKI Surabaya named Puji Kuswati (43) and her two daughters, namely Famela Risqita (9) and Fadhila Sari (12).

Third, the third bomb explosion occurred at the Pentakosta Church. The suicide bomb explosion at the Pentakosta Church occurred at 07.53. The perpetrator named Dita (48). The incident began when a car entered the churchyard and then blew itself up inside the church. The suicide bomb explosion was the last act carried out by one family at three churches in Surabaya, East Java.

\section{Profile of the Perpetrators}

From the acts of terrorism that occurred in three churches in Surabaya, it is important to identify the perpetrators who were directly involved in the suicide bombings that at least killed many people around the Church. From the results of the identification of the policy related to the perpetrators who were directly involved in suicide bombings in the three Surabaya Churches, it is known that one family still has a close relationship, both as a husband, wife, and child, which has become a new trend in the development of terrorism cases that occur in Indonesia.

The main perpetrator of a suicide bombing in Surabaya is known as Dita Priyanto (Chair of JAD, Surabaya). Dita as the main actor in the Surabaya suicide bombing was allegedly the Chairperson of the Surabaya

${ }^{11}$ Muhaimin Zulhair Achsin, "Culture and Role of Women In Terrorism In Indonesia: Case Studies Suicides Bombing in Surabaya and Sibolga," International Journal of Engineering and Advanced Technology (JIEAT) 8, no. 5 (2019): 873-74. 
branch of JAD, which was said to have links to the Ansharut Tauhid (JAT) network. ${ }^{12}$ The two organizations, which have many branches in various regions, are known to have ideological and movement similarities with ISIS in the Middle East. This is one of the terrorist movements known to be very cruel and do everything they can to carry out their attacks.

If viewed from the background and profession of Dita as the main perpetrators of suicide bombings in Surabaya, it cannot be interpreted with logic and common sense. This is because Dita is not a person far from the world of education and comes from the environment and the economic class and above. He is suspected of having a business as a seller of herbal candlenut oil products. When running the business, Dita is assisted by a wife who also works as a nurse in a private hospital in Surabaya. This indicates that the place of residence is far from being dirty or poorly maintained.

The case of Dita's and his family's action shows that the main factor of terrorism involvement is not results from poverty and lack of education. In the case of terrorism that occurred in Surabaya, it turns out that it is completely unrelated to the problem of poverty and low education. However, it is known that Dita as the main perpetrator of this suicide bombing is a figure who comes from the upper-middle class. When it comes to economics, Dita and his family are well-established and wealthy. Then how can he be exposed to radical ideology and choose to become a jihadist in the hope of getting the paradise they want?

Every terrorist act carried out by individuals or groups, indeed cannot be separated from the circumstances and conditions that accompany it, including suicide bombings by one family in Surabaya. If you look to the future, the acts of terror carried out by Dita are inseparable from the ideology and ideology that he believes to be a truth and a jihad movement in the path of Allah. It means, that the radical ideology and ideology manifested in the Dita family is not without a background.

$12 \mathrm{JAD}$ is the largest local terror group who believed to be responsible for multiple deadly bombings in East Java. See Kharishar Kahfi, "JAD Indicted as Banned Terror Organization," Jakarta Post (blog), 25 Juli 2018. 


\section{Motives of the Bombing}

The bombing of the three Churches in East Java cannot be separated from the motivation behind the action taken. Although it can be predicted according to the target, revealing the motivation and background of an event to be something very important in the case of terrorism in Indonesia. The Tempo report states that the number of suicide bombers in three churches in Surabaya reached at least 49 people, with 9 dead and 40 injured.13

There are several motives for the perpetrators to commit cruel acts by suicide bombings and involve their wives and children as part of acts of terror. First, behind the acts of terrorism in Surabaya could not be separated from acts of revenge because one of the leaders of the Jemaah Ansharut Daulah (JAD) Surabaya was ensnared in a criminal terrorism case, namely Aman Abdurrahman. The husband and wife of the four children who have committed suicide bombings are members of JAD Surabaya. The JAD is a modern khawarij which is very dangerous to the continuation of Islam. ${ }^{14}$

Second, the bomb blasts in the three Churches are a series of various religious and terrorism issues that are developing very fast. They have a mission to fight the government which is considered unable to solve the nation's problems. The suicide bombings carried out by terrorists showed a very massive and systematic resistance to make the state's situation more unstable and in an emergency position for terrorism.

Third, the bombing in Surabaya is nothing but to spread fear and damage to the wider community. Although the main target is non-Muslim groups, the impact of suicide bombings also affects innocent Muslims who have no affiliation with terrorist networks or fundamentalist groups that are deeply rooted in religious life in Indonesia.

13 Tempo, 13/05/2018.

14 Dedy Tabrani, "Familial Terrorism: An Anthropological Analysis on Familial Suicide Bombings in Surabaya 13-14 Mei 2018," International Journal of Recent Technology and Engineering (IJRTE) 7, no. 6 (2019): 1443-1444. 


\section{Involvement of Women and Children as a New Trend in Suicide Bombings}

If seen a series of events that occurred, the suicide bombing in Surabaya is an act of terrorism that presents a new trend of carrying out attacks in the field. Among the new trend that occurs in the tragedy of suicide bombings is to involve children as brides of heaven. The involvement of children in terrorism cases is the first case that occurred in Indonesia, because before it had never happened how terrorists bring their children to participate in suicide bombings.

In the view of M. Endy Saputro, women in the context of terrorism networks, often become important agents in creating kinship genealogy through marriage. ${ }^{15}$ This new model is certainly a challenge for the government to break the chain of involvement of women and children as part of the attack operation. The case of a suicide bombing in Surabaya involving one family, including a new model that must be watched out for could be a threat to the resilience of Indonesian families.

The involvement of women in recent years seems to be a new chapter in terrorism cases in Indonesia. The terrorism case in Surabaya involving women is part of a new phenomenon which is quite disturbing and alarming for the nation's journey. However, the terrorist perpetrators in Surabaya who were also women were not the first, but there was the first Indonesian woman who became a terrorist in December 2016, namely Dian Yulia Novi (28), who detonated a pot bomb at the State Palace on December $11,2016.16$

The suicide bombing case in Surabaya is a new phenomenon after Dian's case. Based on the statement of Nassir Abbas, a former member of Jemaah Islamiyah (JI), the terror movement always changes according to the target and the conditions behind it. Currently, women are the main actor as a frightening weapon in terror attacks, accompanied by suicide bombings carried out by involving and involving their children. One of the widespread doctrines of suicide involving women is the number of wives

15 Muhammad Enday Saputro, "Probabilitas Teroris Perempuan di Indonesia," Jurnal Ilmu Sosial dan Ilmu Politik 14, no. 2 (2010): 219-22.

16 Nurhadi Sucahyo, "Perempuan dan Anak Pemantik Detonator," VOA Indonesia (blog), Mei 2018, https://www.voaindonesia.com/a/perempuan-dananak-pemantik-detonator-4394184. 
of terrorist prisoners who often face stigma or negative views from the community, neighbors, and the surrounding environment. ${ }^{17}$

The involvement of women in terrorism cases does not occur spontaneously, because there are developments in technology and social media that also influence the way of society's view of women. ${ }^{18}$ The case of Dian Yulia Novi is a clear example of women's involvement in terrorism networks. This fact confirms that women participated in the vortex of terrorism, in which she admitted that she experienced an indoctrination of jihad through the internet and social media initiated by her husband. ${ }^{19}$ This case is a sign that the wife of a terrorist is very vulnerable to becoming a suicide bomber and becoming a bride in heaven.

The case that happened to Dian, apparently happened to Dita's wife who was a suicide bomber in Surabaya. There are four reasons for women's involvement in the vortex and terrorism networks of their husbands, namely the low level of literacy, exclusive religious interpretation, feeling isolated from their group, and the influence of the husband's ideology. ${ }^{20}$ The involvement of wives and children in terrorism cases is one of the new modes that influence the workings of terrorists in launching their actions. It must be admitted that the wife or woman can be a supporter of the movement or ideology of the husband.

There is an interesting analysis presented by Lies Marcoes, an observer of gender and radicalism issues, that the involvement of women and children in terrorism networks cannot be ignored. In the view of Lies Marcoes, Dian's case is as an active actor, but only on her own and not to launch the action. In the case of a suicide bombing in Surabaya, the position

\begin{tabular}{ccccccr}
\hline 17 & Nassir Abbas, "Perempuan dan & Anak & dalam & Pusaran \\
Terorisme," & CNN & Indonesia & (blog), & Mei & 2018 & dalam
\end{tabular}
https:/ / www.cnnindonesia.com/nasional/20180525083555-12301164/perempuan-dan-anak-di-pusaran-terorisme.

18 Nava Nuraniyah, "Not Just Brainwashed: Understanding the Radicalization of Indonesian Female Supporters of the Islamic State," Terrorism and Political Violence 30, no. 6 (2018): 890-910.

19 Tia Mariatul Kibtiah, "Indonesian Women and Terrorism: ISIS Recruitment Strategy Through Social Media" (ICOBIRD Binus University, Jakarta, 2019), 5-10.

20 Leebarty Taskarina, Perempuan dan Terorisme: Kisah Perempuan dalam Kejahatan Terorisme (Jakarta: PT. Elex Media Komputindo, 2018), 56. 
of women could have been an active offender by allowing their children to be part of the bride of heaven to smooth out the wishes and invitations of the husband. ${ }^{21}$

The Surabaya suicide bombing case emphasized that Dita as the head of the family had a big role in the attack. This is because he is a member of the Jemaah Anshorut Daulah (JAD). However, his wife's position did not carry out a rebellion or reject the desire and invitation of her husband not to involve their children in suicide bombings. Instead, the wife allowed the plan and attack to take place in their family life. In this case, it can be interpreted that Praise obeyed Dita as her husband to carry out suicide bombings justified in the name of religion and culture. ${ }^{22}$

In other words, that women occupy an important position against suicide bombings and attacks- not to say that women are not the main perpetrators- but there is the role of husbands of radical movements carried out, including Surabaya suicide bombings involving one family at once. The following are the results of Lies Marcoes's analysis of the involvement of women in the cases of terrorism..$^{23}$

\section{Table 1}

\begin{tabular}{|l|l|l|}
\hline No & Reasons for Engagement & Description of Engagement \\
\hline 1 & Struggling against tyranny & $\begin{array}{l}\text { The struggle against tyranny and evil is } \\
\text { not just a man's duty, but women also } \\
\text { have a part. Women are active in } \\
\text { recitation activities that encourage people } \\
\text { to fight against anything contrary to } \\
\text { religious teachings. They can be very } \\
\text { active motivators to strengthen the } \\
\text { husband's faith to fight and fight against }\end{array}$ \\
\hline
\end{tabular}

${ }^{21}$ Lies Marcoes, “Bagaimana Para Perempuan Menjadi Pelaku Teror dan Membawa Anak?," BBC News Indonesia (blog), Mei 2018, https://www.bbc.com/indonesia/indonesia-44106870.

${ }_{22}$ Achsin, "Culture and Role of Women In Terrorism In Indonesia: Case Studies Suicides Bombing in Surabaya and Sibolga," 873-74.

${ }^{23}$ Lies Marcoes, "Why Do Indonesian Women Join Radical Groups," Indonesia at Melbourne (blog), November 2015, https://indonesiaatmelbourne.unimelb.edu.au/why-do-indonesian-women-joinradical-groups/. 


\begin{tabular}{|l|l|l|}
\hline No & Reasons for Engagement & Description of Engagement \\
\hline 2 & Join for Jihad & $\begin{array}{l}\text { Women believe that as Muslims, they } \\
\text { must fight in the way of Allah. The big } \\
\text { jihad in the eyes of women is not just } \\
\text { preparing their husband's skills when } \\
\text { they go to war, but also must actively go } \\
\text { to the field by becoming a bomber }\end{array}$ \\
\hline 3 & $\begin{array}{l}\text { Want to be Recognized as aseous } \\
\text { Couragender }\end{array}$ & $\begin{array}{l}\text { The position of women is indeed under } \\
\text { the shadow of men, but women also have } \\
\text { the desire to be recognized as brave to } \\
\text { sacrifice in the way of God. This desire to } \\
\text { be brave further strengthens the position } \\
\text { of women to support the role of jihadi } \\
\text { husbands and even joins husbands to } \\
\text { fight together to become terrorist groups. }\end{array}$ \\
\hline
\end{tabular}

\section{Indoctrination Process in the Surabaya Suicide Bombing}

Before entering the stage of indoctrination in terrorism cases, it is important to first break down the four processes of radicalization carried out by terrorist groups in the case of terrorism in Indonesia. Radicalization is the process a person obtains views or understandings that are considered radical.24 From this process, a person tends to support and justify a religious understanding related to the concept of jihad with the use of violence as a strategy that must be carried out. Below is a table of stages of individual radicalization exposed to radical ideology to the stage of jihadization as the final stage of the movement carried out by radicalterrorist groups. ${ }^{25}$

24 Anne Aly dan Jason-Leigh Striegher, "Examining the Role of Religion in Radicalization to Violent Islamist Extremis," Studies in Conflict E Terrorism 35, no. 12 (2012): 26.

25 Mitchell D. Silber dan Arvin Bhatt, The Radicalization in The West: The Homegrown Threat Prepared (New York: The New York City Police Department, 2007), 21-43. 
Table 2

\begin{tabular}{|l|l|l|}
\hline No & \multicolumn{1}{|c|}{ Radicalization Phase } & \multicolumn{1}{|c|}{ Explanation of Radicalization } \\
\hline 1 & Pre-Radicalization & $\begin{array}{l}\text { The initial stage which gives an } \\
\text { overview of the condition of an } \\
\text { individual or person before entering the } \\
\text { radical-terrorist group. }\end{array}$ \\
\hline 3 & $\begin{array}{l}\text { Self-Identification } \\
\text { individuals who are exposed to radical } \\
\text { indoctrination } \\
\text { ideologies and understandings, both } \\
\text { from the concept of religion and from } \\
\text { the practice of religion itself. This stage } \\
\text { individuals are interested in studying } \\
\text { religion with rigid or textual } \\
\text { interpretation from conservative groups } \\
\text { who are very radical in interpreting } \\
\text { religious teachings }\end{array}$ \\
\hline 4 & $\begin{array}{l}\text { Jihadization } \\
\text { individuals begin to justify and believe } \\
\text { that jihad is the main mission of their } \\
\text { group. This stage the individual } \\
\text { believes that killing the unbelievers is } \\
\text { justified according to the interpretation } \\
\text { of their teachings with the arguments } \\
\text { obtained from the Qur'an and the } \\
\text { hadith. }\end{array}$ \\
\hline $\begin{array}{l}\text { This stage is an individual who has } \\
\text { entered a terrorist act or movement by } \\
\text { becoming a bride in heaven or } \\
\text { committing suicide bombings as part of } \\
\text { a jihadist movement that they believe } \\
\text { in. }\end{array}$ \\
\hline 1
\end{tabular}

The term indoctrination is a process of delivering teachings and beliefs to someone to be internalized in the mind deeply. Indoctrination 
here controls everything that enters the belief system and the human mind and is very decisive for our perspective of ourselves and others. ${ }^{26}$

Indoctrination can be understood as an important process in shaping a suicide bombing in terrorism. The indoctrination process establishes the recruit's position in the terrorist organization, provides education about the group, motivation, and its missions, and develops the recruit's mindset toward executing an attack. Indoctrination is carried out mostly in isolation and recruit are usually encouraged to sever ties with the outside world, in particular family members and friends, especially those who oppose jihad, suicide missions, or care deeply about the recruit. ${ }^{27}$

In this concept of indoctrination, individuals who are indoctrinated have a difference and the character of people who are not indoctrinated in the context of control beliefs. Usually, people who are indoctrinated by a certain ideology, are isolated from the family and the surrounding environment and are very open to the doctrine. His control of beliefs about the relationship between Muslims and non-Muslims greatly limits his intellectual views on the assumption that non-Muslims are common enemies. ${ }^{28}$

Indoctrination can be understood as giving teachings in depth without any criticism by seeing the truth of teaching from one side only. In other words, indoctrination is a process carried out to instill and solidify ideas, attitudes, and behaviors in certain teachings or ideologies by the wishes of the person or group that does so.

And then, how about indoctrination in terrorism cases and radical movements in Indonesia? The strategy of radical-terrorist groups in strengthening their networks is by indoctrination. As it is known that indoctrination in terrorism cases is an important stage in instilling radical ideology in individuals or groups because this stage becomes an entry point for someone to participate in the justification of beliefs and carrying out acts of violence according to the instructions of the group.

${ }^{26}$ Charlene Tan, Islamic Education and Indoctrination: The Case in Indonesia (London: Routledge, 2011), 2-4.

27 Updesh Kumar, Understanding Suicide Terrorism: Psychosocial Dynamic, ed. oleh Manas K. Mandal (New Delhi: SAGE Publications Ltd, 2014), 45-46.

${ }^{28}$ Tan, Islamic Education and Indoctrination: The Case in Indonesia, 25. 
The religious reasoning used by terrorists is eternal happiness that cannot be exchanged for anything. One way to find true happiness is to carry out jihad with suicide bombings to speed up entry into heaven. For them, death is something that is desired in the psyche of those who want to get peace and happiness in heaven.

Suicide bombings are part of aggressive terrorism behavior. In the case of terrorism in Surabaya, death to get God's heaven is the main goal of suicide, and not just an almost certain consequence. Therefore, suicide bombing is better understood and seen as a bomb explosion rather than suicide. So, some consider and believe that suicide bombing is self-sacrifice, which is considered as a holy death. Death for the jihadists is considered the best path to heaven because they want an eternal life that guarantees happiness in the hereafter.

The perpetrators of terrorism, such as the case in Surabaya by involving their wives and children, can be understood as a form of manifestation to get what they believe in, namely belief in God's heaven without reckoning. In some cases of terrorism, the reasons for people deciding to become suicide bombers vary widely and depend on their background. ${ }^{29}$ Some of them are for reasons of justification of religious teachings which oblige to fight infidels, political reasons, deep disappointment, acts of revenge against security, as well as economic problems and injustice in people's lives.

Terrorist perpetrators who carried out bombings in various regions have violated the meaning and concept of jihad as taught by the Prophet Muhammad. Then what is the concept of jihad in Islam that is often misunderstood by the perpetrators of terrorism in carrying out its actions on the ground? Indeed, jihad does not mean holy war as understood by terrorists. This is because jihad means to struggle or hard work to fight lust as the greatest jihad in the world. The greatest jihad according to Muhammad is the jihad of passion against oneself (patience) and the battle against devils. 30

${ }^{29}$ Interview with Khanis on 20 December 2019

30 Fredrick M. Deny, "Islam and Peacebuilding: Continuities and Transitions" dalam Horald Coward dan Gordon S. Smith, Religion and Peacebuilding (Albany: State University of New York, 2004), 135. 
In the case of terrorism in Surabaya, it was allegedly having problems in the matter of theological interpretation. There is a theological problem that is wrapped up with various views to justify the beliefs of religious teachings. This is because religion does not justify actions in the name of religion to kill other humans of different religions. So, in the context of terrorism in Surabaya, the suicide bombing carried out by one family in the name of jihad cannot be justified whatsoever. This exclusive view is engraved in the soul of terrorists who always nurture the fire of hatred and anger towards non-Muslim groups so that they launch their actions without recognizing the limits of humanity.

Suicide bombers in Surabaya Church in 2018, it did not just happen without a background process. Husband and wife can bear their children part of the jihad that they are carrying to get happiness in heaven according to their beliefs. One form of indoctrination carried out on their children is by prohibiting their children from playing outside the house and interacting with people around the house.

Actors of terrorism in Surabaya indoctrinated by giving videos to watch about jihad as a path to the paradise of God. Gradually their souls were absorbed and engraved with the concept of jihad even though they did not understand what the true meaning of jihad was. Gradually they followed their parents, namely carrying out suicide bombings as a form of jihad which they believed to be true. When viewed from the aspect of moral philosophy, what the terrorist actor Dita and his wife do, bring bad moral values and is misleading for their children. ${ }^{31}$ They lose moral values because of the influence and doctrine of parents who invited him to carry out suicide bombings as part of jihad.

At this stage, Dita as the main actor in the Surabaya suicide bombing indoctrinated his wife and children that what will be done is a truth contained in religious teachings. Dita brainwashed his wife and children to follow the path of his life so they could be together in the way of heaven later. This further emphasizes the influence of the mind and emotional closeness between families so that it is easy to believe and believe in the ideology of the father to become a jihadist.

${ }^{31}$ Agustinus W. Dewantara, Filsafat Moral (Yogyakarta: Kanisius, 2017), 21. 
When indoctrination is successfully instilled and taught in-depth to the prospective bride of heaven, the wife and children of Dita will enter a stage of isolation from their environment. The purpose of this isolation is to cover up information or news from the outside so that the parties that are indoctrinated do not get enlightenment from outside to further strengthen the truth they receive. This stage is usually prepared for the bride and groom of heaven who has entered the stage of mentally mentoring to carry out suicide bombings.

In examining in-depth, the terrorism case carried out by Dita, researchers used several theories explaining the effect of indoctrination (inculcation of violent ideology) on one's mind to carry out suicide bombings by their beliefs. If indoctrination is successfully injected within a person, then the process of becoming a jihadist will be more-wide open and provide ample opportunity for other candidates to carry out their actions. Referring to the theory explained by Arie W. Kruglanski "Psychological Factors in Terrorism and Counterterrorism," there are at least three main factors in the formation of indoctrination at the level of individuals, groups, and organizations, namely significance quest, mean to significance, and commitment shift-significance. ${ }^{32}$

The main factor in the realization of indoctrination on Dita and his families was very influential in the decision to carry out suicide bombings in three Surabaya churches. Dita gives confidence to his families that they have nothing to lose with the sacrifices that have been made. Because it will surely get the reward of heaven as the ultimate goal of human life. Some radical-terrorist groups, including Dita, have massively provided the understanding that committing suicide bombings amid society is part of jihad in which one of the rewards in heaven.

In the case of suicide bombing, terrorism is the culmination of pleasure which is very important for the journey of human life to obtain what is aspired. So, indoctrination is not only a deadly weapon and a mainstay for radical groups, but also has significant value that can facilitate the transfer of ideology so that the same understanding, attitude, and

32 Arie W. Kruglanski dan Shira Fishman, "Psychological Factors in Terrorism and Counterterrorism: Individual, Group, and Organizational Levels of Analysis," Social Issues and Policy Review 3, no. 1 (t.t.): 10-11. 
action are formed in carrying out the holy mission. Women are very vulnerable to being trapped by the indoctrination effects taught by their husbands, so they decide to commit suicide bombings. 33

Indoctrination influences in reinforcing one's commitment and readiness to commit suicide bombings. ${ }^{34}$ This stage is often done and is a key factor in the success of the massive indoctrination of the bride and groom of heaven. First, field training. This stage is done to prepare the mental and physical prospective bride of heaven when it has been indoctrinated by a brainwasher. This training is also conducted in private and is limited to groups. Second, education. This stage is done to strengthen confidence based on the teachings and education that have been received. This stage is also to strengthen the belief that jihad is a shared obligation to fight infidels. Third, the sacred promise. This stage is carried out to test the loyalty of members as a jihadist group. This stage is a stage of commitment for each member to be willing to die as a martyr and must not cancel the intention to carry out a suicide bombing. Fourth, the jihadist period. This stage is the last stage of the indoctrination.

\section{E. A Psychological Analysis of Brainwashing Stages in The Case of Suicide Bombings}

Before researchers further explore how the process of brainwashing in terrorism cases in Surabaya, it is important to know the meaning of term brainwashing from a scientific perspective. The term brainwashing was first discovered by an American journalist named Edward Hunter in one of his works entitled "Brainwashing in Red China". 35 The term brainwashing is very much related to cleansing the mind of a certain paradigm or view point so that it changes completely from before.

The concept of brainwashing in the study of psychology can be understood as a change of mind that occurs radically, because people experience a wave of drastic changes from before, including changes in

${ }^{33}$ Fitriani dan Alif Satria, "The Women Who Seek Meaning in Terrorism," Jakarta Post, 17 Mei 2018.," Jakarta Post (blog), Mei 2018.

34 Kruglanski dan Fishman, "Psychological Factors in Terrorism and Counterterrorism: Individual, Group, and Organizational Levels of Analysis," 20.

${ }^{35}$ Kathleen Taylor, Brainwashing: The Science of Through Control (New York: Oxford University Press, 2014), 3-4. 
beliefs or ideologies that are embedded in his soul. Confidence in brainwashing does present a concept that is deeply rooted without going through a process of learning or prior consideration. That is, belief is part of the situation or state of mind of a person or individual to accept the truth of certain objects in their environment. ${ }^{36}$

The way brainwashing works is not the same as a lower-level indoctrination process. Brainwashing activities in humans are usually carried out on alpha brain waves as a phase of the human conscious mind state which then enters the unconscious mind (subconscious). ${ }^{37}$ In this context, the human conscious and subconscious mind directly influences how the brain in charge of filtering the power and thought programs that want to enter or exit the conscious and subconscious mind. In it, there is a Reticular Activating System that can produce stress, tension, or changes in mindset that can be harmful to the system and the work of the human brain in carrying out any activity.

In the first stage, the brainwashing system works by controlling the environment of the bride and groom or new members who will enter the terrorism network. A terrorist tries to cut off relations or interactions with the outside world that are deemed incompatible with their network ideology or ideology. The next stage is the brainwasher trying to paralyze the previous beliefs to promote new beliefs that are by the ideology and ideology of terrorist organizations.

When new beliefs have begun to enter the mind and way of brainwashing, the next stage is indoctrination, which is the stage of giving teachings in-depth to prospective new members to enter the terrorism network. The teachings given are true teachings based on the results of indoctrination carried out to bring new beliefs that are more valuable in the lives of individuals who have entered the terrorism network.

The following is how the brainwashing works that are given to the bride of heaven. First, environmental control. The brainwashing process restricts and even interrupts communication with the outside environment, both communication with family, friends, people around. Second, the

36 Taylor, 3-4.

37 Djohan Gunawan, Lawan Bahaya Cuci Otak dan Pengendalian Pikiran (Jakarta: PT. Elex Media Komputindo, 2011), 21-22. 
paralysis of the brain's work. Brainwasher starts working to paralyze his beliefs and understandings. The method used was to use torture methods mentally and physically. One aim is to shake beliefs held previously and incorporate new beliefs. Third, indoctrination. Brainwasher begins to put new beliefs and insights into the minds of people affected by brainwashing viruses. Fourth, guarding beliefs. Brainwasher began implementing the reward and punishment method for brainwashing victims.

Before presenting how the brainwashing process in terrorism cases, researchers first want to give an idea of the pattern or stages of recruiting new members or prospective brides of heaven who have been indoctrinated by brainwashers. Cases of brainwashing are always correlated with recent cases of terrorism, such as the case of Dita and her family who have carried out the stages of indoctrination and jihadization.

This brainwashing case in the world of terrorism has become a special spice that will continue to roll until there is a stage where the brainwashers successfully launch actions and instill teachings by the wishes of radical-terrorist groups. There are three stages of brainwashing for the bride of heaven, namely the process of recruiting the bride of heaven, the stage of indoctrination, and the stage of isolation to launch an attack.

These stages illustrate the journey of Dita and his family as suicide bombers in Surabaya, East Java. The initial stage is the stage where Dita as the main actor behind the suicide bombings by inviting his wife and children, is designed as a prospective bride of heaven with promises that have been spread by the brainwasher. At this stage, Dita forced herself to invite and control his wife and children to follow in his footsteps and equally enter heaven through suicide bombings as the best path in his life.

The case of Dita and his family involved in suicide bombings in three churches implies a message that brainwashing has been successfully carried out by radical-terrorist groups to expand the wings of networks and organizations that are increasingly massive in the lives of Indonesian people. The success of the radical-terrorist groups was alleged as their efforts in igniting the fire of jihad as a justification in carrying out acts of violence and suicide bombings with almost the same pattern. 


\section{F. Conclusion}

The religious reasoning used by terrorists is eternal happiness to Allah's paradise. One way to find true happiness is to carry out jihad with suicide bombings to speed up entry into heaven. For terrorists, death by suicide bombing is part of jihad to get peace and happiness in paradise. For suicide bombers in Surabaya, bombing the Church is a form of jihad in defense of religion. The church is a symbol of infidels who must be destroyed in this life. This jihadist movement signifies that radical-terrorist groups have an exclusive view internalized in the soul to carry out suicide bombings.

In the Surabaya terrorism case with a suicide bombing, there was an indoctrination process and signs of brainwashing that were very massive in launching suicide bombings. Moreover, not only Dita as the head of the family was detected exposed to radical movements and in the end, did a jihadist action, but also involved his wife and children as the bride of heaven[.]

\section{REFERENCES}

Abbas, Nassir. "Perempuan dan Anak dalam Pusaran Terorisme." CNN Indonesia (blog), Mei 2018.

Achsin, Muhaimin Zulhair. "Culture and Role of Women In Terrorism In Indonesia: Case Studies Suicides Bombing in Surabaya and Sibolga." International Journal of Engineering and Advanced Technology (JIEAT) 8, no. 5 (2019).

Aly, Anne, dan Jason-Leigh Striegher. "Examining the Role of Religion in Radicalization to Violent Islamist Extremis." Studies in Conflict $\mathcal{E}$ Terrorism 35, no. 12 (2012).

Brym, Robert J., dan Bader Araj. "Suicide Bombings as Strategy and Interaction: The Case of the Second Intifida." Social Forces 84, no. 4 (2006). 
Coward, Horald, dan Gordon S. Smith. Religion and Peacebuilding. Albany: State University of New York, 2004.

Dewantara, Agustinus W. Filsafat Moral. Yogyakarta: Kanisius, 2017.

Fitriani, dan Alif Satria. "The Women Who Seek Meaning in Terrorism," Jakarta Post, 17 Mei 2018." Jakarta Post (blog), Mei 2018.

Gunawan, Djohan. Lawan Bahaya Cuci Otak dan Pengendalian Pikiran. Jakarta: PT. Elex Media Komputindo, 2011.

Hendropriyono, A.H. Terorisme: Fundamentalisme Kristen, Islam, dan Yahudi. Jakarta: Kompas, 2009.

Ismail, Noor Huda. "Ideologi Kematian Keluarga Teroris." CNN Indonesia (blog), Mei 2015. https://m.cnniindonesia.com/nasional/20180515.

Kahfi, Kharishar. "JAD Indicted as Banned Terror Organization." Jakarta Post (blog), 25 Juli 2018.

Kibtiah, Tia Mariatul. "Indonesian Women and Terrorism: ISIS Recruitment Strategy Through Social Media." Jakarta, 2019.

Knop, Katharina Von. “The Female Jihad: Al-Qaedah's Women." Studies in Conflict $\mathcal{E}$ Terrorism 30, no. 5 (2007).

Kruglanski, Arie W., dan Shira Fishman. "Psychological Factors in Terrorism and Counterterrorism: Individual, Group, and Organizational Levels of Analysis." Social Issues and Policy Review 3, no. 1 (t.t.): 2009.

Kumar, Updesh. Understanding Suicide Terrorism: Psychosocial Dynamic. Disunting oleh Manas K. Mandal. New Delhi: SAGE Publications Ltd, 2014.

Marcoes, Lies. “Bagaimana Para Perempuan Menjadi Pelaku Teror dan Membawa Anak?" BBC News Indonesia (blog), Mei 2018. https://www.bbc.com/indonesia/indonesia-44106870. 
- - -. "Why Do Indonesian Women Join Radical Groups." Indonesia at Melbourne (blog), November 2015. https:/ / indonesiaatmelbourne.unimelb.edu.au/why-doindonesian-women-join-radical-groups/.

Nuraniyah, Nava. "Not Just Brainwashed: Understanding the Radicalization of Indonesian Female Supporters of the Islamic State." Terrorism and Political Violence 30, no. 6 (2018).

Pape, Robert A. Dying to Win: The Strategic Logic of Suicide Terrorism. New York: Random House Trade Paperbacks, 2006.

Pettifor, Lloyd, dan David Holding. Terrorism: The New World War. Bookmart Limited, 2003.

Rajan, V.G. Julie. Women Suicide Bombers: Narrative of Violence. New York: Routledge, 2011.

Saputro, Muhammad Enday. "Probabilitas Teroris Perempuan di Indonesia." Jurnal Ilmu Sosial dan Ilmu Politik 14, no. 2 (2010).

Sarwono, Sarlito Wirawan. Terorisme di Indonesia; dalam Tinjauan Psikologi. Jakarta: Pustaka Alvabet, 2012.

Schulze, Kirsten E. "The Surabaya Bombings and the Evolution of The Jihadi Threat in Indonesia." Combating Terrorism Center 11, no. 6 (2018).

Silber, Mitchell D., dan Arvin Bhatt. The Radicalization in The West: The Homegrown Threat Prepared. New York: The New York City Police Department, 2007.

Sucahyo, Nurhadi. "Perempuan dan Anak Pemantik Detonator." VOA Indonesia (blog), Mei 2018. https://www.voaindonesia.com/a/ perempuan-dan-anakpemantik-detonator-4394184. 
Tabrani, Dedy. "Familial Terrorism: An Anthropological Analysis on Familial Suicide Bombings in Surabaya 13-14 Mei 2018." International Journal of Recent Technology and Engineering (IJRTE) 7, no. 6 (2019).

Tan, Charlene. Islamic Education and Indoctrination: The Case in Indonesia. London: Routledge, 2011.

Taskarina, Leebarty. Perempuan dan Terorisme: Kisah Perempuan dalam Kejahatan Terorisme. Jakarta: PT. Elex Media Komputindo, 2018.

Taylor, Kathleen. Brainwashing: The Science of Through Control. New York: Oxford University Press, 2014.

Widyaningsih, Rindha. "Family Suicide Bombing: A Psychological Analysis of Contemporary Terrorism." Walisongo: Jurnal Penelitian Sosial Keagamaan 16, no. 2 (2018). 